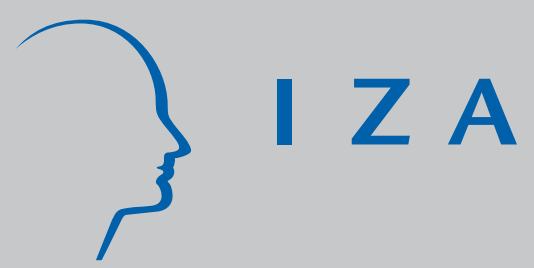

IZA DP No. 896

What Can We Learn About the Decline in U.S. Union Membership from International Data?

Solomon W. Polachek

October 2003 


\title{
What Can We Learn About the Decline in U.S. Union Membership from International Data?
}

\author{
Solomon W. Polachek \\ State University of New York at Binghamton \\ and IZA Bonn
}
Discussion Paper No. 896
October 2003

\author{
IZA \\ P.O. Box 7240 \\ D-53072 Bonn \\ Germany \\ Tel.: +49-228-3894-0 \\ Fax: +49-228-3894-210 \\ Email: iza@iza.org
}

This Discussion Paper is issued within the framework of IZA's research area Internationalization of Labor Markets. Any opinions expressed here are those of the author(s) and not those of the institute. Research disseminated by IZA may include views on policy, but the institute itself takes no institutional policy positions.

The Institute for the Study of Labor (IZA) in Bonn is a local and virtual international research center and a place of communication between science, politics and business. IZA is an independent, nonprofit limited liability company (Gesellschaft mit beschränkter Haftung) supported by Deutsche Post World Net. The center is associated with the University of Bonn and offers a stimulating research environment through its research networks, research support, and visitors and doctoral programs. IZA engages in (i) original and internationally competitive research in all fields of labor economics, (ii) development of policy concepts, and (iii) dissemination of research results and concepts to the interested public. The current research program deals with (1) mobility and flexibility of labor, (2) internationalization of labor markets, (3) welfare state and labor market, (4) labor markets in transition countries, (5) the future of labor, (6) evaluation of labor market policies and projects and (7) general labor economics.

IZA Discussion Papers often represent preliminary work and are circulated to encourage discussion. Citation of such a paper should account for its provisional character. A revised version may be available on the IZA website (www.iza.org) or directly from the author. 
IZA Discussion Paper No. 896

October 2003

\section{ABSTRACT}

\section{What Can We Learn About the Decline in U.S. Union Membership from International Data?*}

This paper is composed of two parts. First, using international data, I corroborate that union density in the U.S. declined because of asymmetric growth between the union and nonunion sectors. I show union density to increase in countries experiencing strong manufacturing growth, and to decline in countries undergoing large women's increases in nonagricultural employment. Second, I borrow from international relations research on war and peace to develop a cogent reason why union density differs by sector. In this vein, I apply a model primarily used to describe bilateral political interactions to figure out why workers often engage in hostile activities such as strikes. In doing so, I look at the contentious rather than the cooperative "face" of unions.

JEL Classification: J4, J5, F16

Keywords: unions, union density, manufacturing growth, international relations

Solomon W. Polachek

Department of Economics

State University of New York at Binghamton

Binghamton, New York 13902-6000

USA

Tel.: +16077776866

Email: polachek@binghamton.edu

\footnotetext{
* This paper is based on material presented at the 2002 Twenty-third Annual Middlebury Conference on Economic Issues, this year on the Changing Role of Unions. I would like to thank Jeff Xiang for valuable research assistance and Richard Freeman for important comments.
} 
What can we learn about the decline in U.S. union membership from international data?

\section{Background}

What is common knowledge regarding union membership? A quick read of several elementary textbooks indicates not only a declining U.S. union membership since the 1950s, but also diminishing union membership in the UK beginning in the late 19705 . However, these trends in American and British unionism were not necessarily typical worldwide. As shall be illustrated very shortly, although the rate of union membership was deteriorating in a number of countries, such as Canada, France, Spain, Chile, and Kenya, it was increasing in Norway, Sweden, as well as a number of developing countries, (e. g. Mexico, Korea, and Taiwan). So not all countries mirror the US's and UK's decline in union membership.

In an exceedingly interesting analytical and econometric paper, Henry Farber and Bruce Western provide an explanation for the decline in US union membership 4 They argue convincingly that in the U.S. the nonunion sector is growing far more quickly than the union sector. This asymmetric growth implies that non-union employment is increasing while union employment is shrinking. As such, the proportion of the workforce that is union is declining. Put simply, the

\footnotetext{
${ }^{1}$ Textbooks with data on these trends include Borjas (2000), Ehrenberg and Smith (2000), Kauffman (1994), and Polachek and Siebert (1993). Monographs include Hirsch-Addison (1986) and Booth (1995). One of the early studies on the subject (Dickens-Leonard, 1985) attributes the decline to structural changes, particularly occupational, educational and gender distribution of the workforce. Ironically this study on union membership decline builds on a literature analyzing American trade union growth (Ashenfelter-Pencavel, 1969).

${ }^{2}$ Freeman (1988) alludes to these international differences.

${ }^{3}$ One could ask whether union membership is the appropriate variable when considering the general topic of union power. Indeed one easily may argue that the decline in union membership understates the decline in union power for two reasons: First, data on strikes (UK) are down. Second, data presented in this volume by Barry Hirsch, David Macpherson, and Edward Schumacher imply that U.S. union success in achieving wage gains diminished. So one question is how important is union membership in assessing union power. I am not going to look at this question. Instead, I am going to look at the question Henry Farber and Bruce Western actually addressed on union density.

${ }^{4}$ Also see, Farber (1990) and Farber and Western (2000,2001).
} 
economy is divided into two parts: a union segment which appears to be shrinking, and a nonunion segment, which in contrast is expanding.

Farber and Western's chapter relies solely on U.S. data to prove its point. Yet declining union membership patterns are not the norm for all countries. Thus it is not obvious the same conclusions would be reached if international data were explored. But even if similar conclusions were reached, it would be instructive to see if international data sheds light on the reasons why separate union and nonunion sectors emerged in the first place. The purpose of this paper is to use international data, albeit with a different empirical methodology, to see if conclusions similar to Farber and Western are attained. In addition, the paper suggests an interesting reason based on international relations research why certain economic sectors tend to be union, while others tend to be nonunion.

\section{International Data}

Because of the non-uniform international trends in union density, I believe it instructive to examine the international data more carefully particularly assessing what one can learn about secular changes in union density. As is it turns out, the task is made easier because Walter Galenson compiled data on eleven variables for 25 countries over most of the 1980-1990 decade.

The Galenson data include: industrial status, GDP growth, the percentage change in manufacturing employment, the percentage change in employee earnings in manufacturing, the average annual price inflation, the average annual unemployment rate, the proportion of nonagricultural female employment, and government attitudes towards unions. Only for developed 
countries are social security benefits data available. They are measured as Social security benefits as a proportion of GDP. Appendix Table A contains the full set of data.

The union density is given for 1980. Union growth rates are from 1980 to 1988. About half the countries Galenson includes are industrial, and about half are developing. The GDP annual growth rate is for 1980-1989, as is the change in manufacturing employment. As will be shown, this latter variable is important because the manufacturing sector tends to be union. Also key to the Farber-Western hypothesis is the proportion of females in the economy since female sectors tend to be nonunion.

Galenson's measure of the government attitude towards unions is an assessment he computed himself based on his institutional knowledge of each country. The ranking goes from one to five, where five is most favorable. The US achieves a two, which is the lowest in the data. This ranking is shared with the UK, Chile, Kenya, Taiwan and Thailand. On the other extreme are Australia, Norway and Sweden with a ranking of five, the most favorable towards unions. The variable means are given in Table 1.

Galenson divides the union membership data into two groups: industrial and developing countries. I replicate these in Table $2 \frac{6}{6}$ It is obvious union density declined in each industrial country, with the exception of Sweden and Norway. Thus these patterns are generally consistent with the US. But for the developing countries, the story is a bit more mixed. Some countries

\footnotetext{
${ }^{5}$ See Walter Galenson (1994). Whereas Galenson discusses qualitatively how each data series relates to unionization, he never performs a rigorous statistical analysis relating each time-series.

${ }^{6}$ Not all Galenson's data represent eight-year (1980-88) growth rates. Thus in Table 1, I extrapolated Galenson's data when the full eight year period was not given in his original Table.
} 
increase union density whereas some decrease union density. Kenya and India exhibit significant declines in union membership. Union membership rates are declining is the South American countries, but the rates vary from $-36.4 \%$ for Chile to $-7.2 \%$ for Brazil. Kenya's decline is $36.1 \%$. On the other hand, the Philippine's union density is increasing 4\%. Mexico's is increasing $21.9 \%$, Taiwan's is increasing $40.8 \%$, and Korea's by $52.2 \%$.

Though Galenson doesn't perform statistical analysis relating the variables, his book serves as a data compendium. These data can be used to reach conclusions based on the statistical tests I perform below. But first, more specifics with respect to the approach.

\section{Modeling Union Membership Change}

Farber-Western use an accounting framework to decompose the U.S. decline in union membership into two components: 1) the level of union organizing and 2) the differential in employment growth in union and nonunion sectors.

\section{Accounting for Union Density}

To account for the decline in union density, Farber and Western model the proportion of the workforce unionized. They define this proportion at time $\mathrm{t}$ to be

(1) $r_{t}=\frac{U_{t}}{U_{t}+N_{t}}$

where $U_{t}$ and $N_{t}$ depict time temployment in the union and nonunion sectors respectively. They go on to define dynamic adjustment equations defining how union and nonunion employment evolves 
based on each sector's prior period's employment, $U_{t-1}$ and $N_{t-1}$, evolutionary parameters $\theta_{t}$ and $\phi_{t}$ depicting union and nonunion employment growth, as well as a new-organization rate parameter $\psi_{t}$ portraying the fraction of potential nonunion employment unions successfully organize. These formulations lead to an expression for the required union new-organization rate $\left(\psi_{t}\right)$ that is necessary to maintain a steady state rate of unionization ( i.e., the $\psi_{t^{s s}}$ necessary to maintain $r_{t^{s}}$, defined as the $r_{t}$ to occur when $r_{t}=r_{t-1}$ )

$$
\psi_{t^{s s}}=r_{t^{s s}} \frac{\delta_{t}}{1+\delta_{t}}
$$

The variable $\delta_{t}$ is the rate of employment growth in the nonunion sector $\left(\phi_{t}\right)$ relative to the rate of growth in the union sector $\left(\theta_{t}\right)$. Thus $\delta_{t}$ is defined as $\delta_{t}=\left(\frac{1+\phi_{t}}{1+\theta_{t}}-1\right)$, which has a positive value when the nonunion sector grows more quickly than the union sector (and a value of zero when both sectors grow equally fast). Since $\frac{\partial \psi_{t^{s s}}}{\partial \delta_{t}}>0$, the rate of union organizing need rise in order to maintain a steady state rate of unionization as relative nonunion employment climbs. Indeed as already mentioned above, Farber and Western show that unions would have had to organize at a rate twenty times the current rate to yield union membership rates equal to that in the 1950s, given current levels of $\delta_{t}$. But given current organizing costs, achieving these rates of union organizing are prohibitively expensive. Hence Farber's and Western's pessimistic view on the future of U.S. unionization arises because of the high nonunion sector relative employment gains $\delta_{t}$. 


\section{Modeling Union Membership Change: Union Membership and Sector Specific Growth}

Is the Farber-Western explanation applicable to the above patterns of international union membership change?

As seen, Farber and Western argue that union membership expansions and contractions are based on non-neutral economic growth. Union sector employment is shrinking relative to nonunion sector employment. Consistent with this story, are four factors that underlie the decline in the union sector: (1) the expansion of the service and trade industries which are typically nonunion, (2) the influx of traditionally nonunion women in the workforce, (3) the rise of the South, and (4) the growth in white-collar occupations. With the exception of point (3), which is unique to the United States, Galenson's international data can be used to test these implications of the Farber-Western hypothesis.

In the analysis to follow, I look primarily at the factors that correlate with union membership change. I concentrate mostly on factors related to industrial shifts, but also look at general economic variables such as inflation, employment and social services and income. If Farber-Western are correct, then primarily industrial shift type variables would be related to union membership changes. Of the variables in the data set, these include the percentage change in manufacturing and the percentage change in female employment.

I begin with the Farber and Western hypothesis regarding the importance nonunion employment gains. Essentially, I model how $\delta_{t}$ affects $r_{t}$. Using the Farber-Western notation 
(3) $\quad r_{t}=\frac{r_{t-1}+\psi_{t}\left(1+\delta_{t}\right)\left(1-r_{t-1}\right)}{r_{t-1}+\left(1+\delta_{t}\right)\left(1-r_{t-1}\right)}$.

As indicated in (3), the current unionization rate $r_{t}$ is a function of the past unionization rate $r_{t-1}$ and the current relative rate of employment growth in the nonunion sector relative to the union sector $\delta_{t}$, given the current level of new union organization $\psi_{t}$. One can show that

$$
\frac{\partial r_{t}}{\partial \delta_{t}}=\frac{\psi_{t}\left(1-r_{t-1}\right)}{r_{t-1}+\left(1+\delta_{t}\right)\left(1-r_{t-1}\right)}-\frac{\left(r_{t-1}+\psi_{t}\left(1+\delta_{t}\right)\left(1-r_{t-1}\right)\right)\left(1-r_{t-1}\right)}{\left(r_{t-1}+\left(1+\delta_{t}\right)\left(1-r_{t-1}\right)\right)^{2}}<0
$$

for relevant values of $r_{t-1}, \psi_{t}$, and $\delta_{t}$.

I test whether (4) holds with international data. To test (4), I specify (3) as follows:

$$
r_{i, t}=f\left(r_{i, t-1}, \delta_{i, t}, \psi_{i, t}\right)+\varepsilon_{i, t}
$$

where $\mathrm{i}$ indexes a particular country and t a particular time period, and where $\varepsilon_{i t}$ depicts countrytime specific errors. Of course, one can take the first difference of equation (5) to net out the country-specific effects.

But before presenting the analysis, a word regarding the relationship between the FarberWestern notation and the Galenson variables is in order. First, Galenson's union density is synonymous with $r_{t}$, and the 1980-1988 union growth rate is synonymous with the first difference of $r_{t}$. Second, The Farber-Western variable $\delta$ denotes relative nonunion-to-union employment growth, which reflects increased employment in non-manufacturing and male-dominated industries. 
In addition, the Galenson data contain two related variables: the proportion of nonagricultural female employment and the percentage change in manufacturing employment. The proportion of nonagricultural female employment is positively related to $\delta_{t}$, and the percentage change in manufacturing employment is inversely related to $\delta_{t}$. Thus

$$
\delta_{t}=\delta_{t}\left(L_{F}, L_{M}\right)
$$

where $L_{F}$ and $L_{M}$ represent the proportion of nonagricultural female employment and the level of manufacturing employment, respectively.

Third, none of the Galenson variables directly measure union organizing. However, the percentage change in manufacturing earnings $\left(\dot{Y}_{M}\right)$, the percentage change in $\operatorname{GDP}(\dot{Y})$, the average annual inflation $\left(\dot{Y}_{R}\right)$, the unemployment rate $(\mathrm{U})$, and government attitudes towards unions $(\mathrm{G})$ are all related to the costs and benefits of organizing, $\psi_{t}$. Based on my notions of models describing union organizing my best guess is that one can define

$$
\psi_{t}=\psi_{t}\left(\dot{Y}_{M}, \dot{Y}_{,} \dot{Y}_{R}, U, G\right)
$$

such that $\frac{\partial \psi_{t}}{\partial \dot{Y}_{M}}>0, \frac{\partial \psi_{t}}{\partial Y}>0, \frac{\partial \psi_{t}}{\partial \dot{Y}_{R}}>0, \frac{\partial \psi_{t}}{\partial U}<0$, and $\frac{\partial \psi_{t}}{\partial G}>0$. Hence the Galenson variables are applicable to test Farber and Western's model. 
To set the stage, I first do a simple correlation to find the variables related to union growth. These are presented in Table 3. Following this (also in Table 3), I perform regression analyses with the union growth rate as the dependent variable. Because countries were diverse and varied so much in size, I performed various type regression analyses with several weighting schemes. The results were consistent no matter what weights I used. Thus the analysis presented here is unweighted.

\section{Union Membership and Sector Growth}

Begin with the simple correlations (Column 1, Table 3). First, there is a positive relation between the percentage change in manufacturing employment $\left(L_{M}\right)$ and the growth rate in unionization $\dot{r}_{t}$. As the manufacturing sector grows, union density increases. This finding is consistent with the Farber-Western story, since $\partial \delta_{t} / \partial L_{M}<0$. Also consistent (though one could question the level of significance) is that the negative relation between the proportion of females in the economy and the lower the rate of union growth. This is because the female sectors tend to be nonunion, or in Farber and Western's notation, $\partial \delta_{t} / \partial L_{F}>0$. Thus, at least using international data, these two findings are consistent with Farber and Western's U.S. results.

Substituting (6) and (7) into (5) and subtracting the lagged union membership to get at the change in variable analyzed by Farber-Western yields the estimable equation (8) utilizing the Galenson variables $\square$

\footnotetext{
${ }^{7}$ I also augmented the model by introducing a dummy variable representing countries with union-managed unemployment schemes (Ghent countries). These constituted Denmark and Sweden in the Galenson sample. The coefficient came out positive (as in Blaschke, 2000) though statistically insignificant.
} 


$$
r_{i, t}-r_{i, t-1}=g\left(L_{F_{i, t}}, L_{M_{i, t}}, \dot{Y}_{M_{i, t}}, \dot{Y}_{i, t}, \dot{Y}_{R_{i, t}}, U_{i, t}, G_{i, t}\right)+\varepsilon_{i, t} .
$$

The exact estimation technique should be based on various assumptions regarding the functional form $g$ as well as the error structure. Parameter estimates assuming a linear specification are presented in Table 3.

Column 2 presents results with each independent variable in a specification including the constant. But to increase sample size, the unemployment variable is omitted in Column3. (Note according to Table 2 there are seven countries with missing values). Finally in Column 4 the specification follows a first-difference type specification and omits the constant ${ }^{\beta}$ Consistent with the simple correlation results already presented, $L_{M}$ is positively related to union membership growth, and $L_{F}$ is negatively related to union membership growth. These results are consistent with Farber-Western. Also, the predictions of equation (7) are borne out in the results. As can be seen, the percentage change in manufacturing earnings $\left(\dot{Y}_{M}\right)$ is positively related to union membership growth. The percentage change in GDP $(\dot{Y})$ is positively related to union membership growth. The average annual inflation $\left(\dot{Y}_{R}\right)$ is positively related to union membership growth. The unemployment rate (U) is negatively related to union membership growth. And finally, positive government attitudes towards unions $(\mathrm{G})$ are positively related to union membership growth.

\footnotetext{
${ }^{8}$ Unlike the typical first-difference approach, not all independent variables are differenced because time-series changes were not available.
} 


\section{Why Is Union Density Sector-Specific? Applying International Relations Literature to get an}

\section{Answer.}

What can be learned from these results? First, there is some evidence that variables pertaining to the costs and benefits of organizing new union members matter. Second, there is some consistency with the story that asymmetric sector-specific economic growth has implications for union membership. Both Farber-Western and the international data presented indicate that union membership expansion is linked to growth in the manufacturing sector. Growth in female dominated industries lessens union membership growth. So the underlying changes in union density within the United States and across countries seems to be related to asymmetric sector-specific economic growth. Growth in manufacturing tends to increase unionization, while industrial growth in sectors concentrated by women tend to lessen unionization. Thus, it makes sense that to better comprehend the unionization process, one needs to figure out why unions pervade manufacturing more so than other sectors. To do that, one should examine union density by economic sector.

In this vein, I assess the percent change in total union membership by industry. Table 4 contains the data for the US and Canada. Despite strong consistency between the US and Canada especially in public sector union membership rates, one can see very big differences across industries. Slight differences pervade in the auto industry probably because some manufacturing might have moved to Canada from the United States. To exemplify these sector differences (Table 5). I present union membership and union coverage data by occupation. 10 Clearly unionization

\footnotetext{
${ }^{9}$ The proportion (rather than the change in proportion) of the industry that is unionized would have been a more appropriate statistic, but Galenson's book did not provide that data.

${ }^{10}$ Rates of unionization vary workers' education levels and industry. However, for now I treat occupations as sectors and concentrate on them.
} 
varies dramatically. Operatives have twice the rate of union membership than laborers and craftsmen, $51 \%$ versus $24 \%$. Clerical and sales workers are somewhat unionized at $17 \%$. Farmers are barely unionized at all. If one treats these occupations as sectors, then these data are consistent with the sector-specific unionization patterns alluded above. But the real challenge is to address the issue why there are sector specific unionization rates. I know of no direct literature on this -- but the question regarding why union membership rates differ by sector is important. I believe one can analyze this question using tools from international relations.

One strand of international relations literature seeks to explain why a particular country, for example the United States, has poor relations with a given country, such as North Korea, better relations say with China, and very good relations with a country like Canada or England. This literature links conflict and cooperation to economic trade. The logic is simple: If conflict leads to a cessation of trade, then the cost of conflict (all else constant) is the lost gains from trade. ${ }_{\text {The }}$ higher these gains from trade losses, the more important is trade in deterring conflict and promoting peace. Thus country pairs with the most trade tend to exhibit the most cooperation and the least hostilities between themselves. Empirical work tends to support this contention.

Is there an analogue between occupations and union membership rates? Clearly, all workers and firms trade. Workers provide a service, and firms bestow a wage. But some employers and employees trade more than is indicated by a simple fee for service transaction. These are the workers and firms that receive and provide specific training. For these workers and firms, not only is there the traditional fee for service transaction, but there is a sharing of the costs and benefits of

\footnotetext{
${ }^{11}$ The same argument applies when conflict leads to a weakening of the terms of trade, rather than a complete cessation of trade.
} 
training. Such sharing brings about incentives for neither the employee nor the employer to interrupt the investment process with a premature quit or layoff. Some occupations are more amenable to this type training than others, as are some industries. If the theory of conflict and trade is applicable, then those occupations (or industries) with the most specific training should see the least unionization and strike activity. Considering union membership to be related to specific training is consistent with "union membership being an experience good".

There are very little data on specific training. However, one proxy is the tenure-wage gradient. The more quickly wages rise with tenure the greater the specific training. In turn, the greater the specific training, the lower the union membership and strike activity. To test this proposition I examined tenure gradients for each occupation. ${ }^{45}$ sing these gradients, I estimated a logit predicting union membership for each occupation. The proportion of intra-occupation union differences predicted by these gradients is given in Table 6. As can be seen, worker firm trade explains $10 \%$ or more of the union membership differences in 23 of the 28 possible inter-occupation categories.

\section{Conclusions}

The Farber-Western results are important. They show that union density in the U.S. declined because of asymmetric growth between the union and nonunion sectors. The nonunion sector grew

\footnotetext{
${ }^{12}$ See Edward Mansfield and Brian Pollins (forthcoming) for evidence pro and con.

${ }^{13}$ See Kuratani (1973) and Hashimoto (1981).

${ }^{14}$ See Rafael Gomez and Morley Gunderson, "Union Membership as an Experience Good for Youth," in this volume.

${ }^{15}$ This analysis is preliminary because in computing the tenure-wage gradient, I did not take account of (1) the correlation between individual differences and both wages and mobility and (2) the correlation between overall job experience, tenure, and job match quality.
} 
more quickly than the union sector. Changes in union organizing to stimulate new membership had little effect to moderate this decline. These results stimulate one to think more deeply why union densities differ by sector.

This paper is composed of two parts. First, I corroborate Farber and Western's hypothesis using international data. I show union density to increase in countries that are experiencing manufacturing growth. Second, I borrow from international relations research on war and peace to develop a cogent reason why union density differs by sector. In this vein, I apply a model primarily used to describe bilateral country interactions to figure out why workers often engage in hostile activities such as strikes. In doing so, I look at the contentious rather than cooperative "face" of unions.

The "conflict-trade" model in international relations research claims that gains from trade motivates friendly political interactions among trading partners. As gains from trade rise, the dealings become more affable. Analogously in industrial relations, worker-firm relations fortify themselves as workers and firms augment their own trade dependencies. One form of trade dependency is specific training, in which workers and firms share the costs and benefits of corporate specific training. This paper shows that specific training differences among workers explains a significant portion of observed union density differences between occupations. 


\section{References}

Derek Aldcroft and Michael Oliver (2000), Trade Unions and the Economy: 1870-2000, (Aldershot, England and Burlington Vt: Ashgate Press).

Orley Ashenfelter and John Pencavel (1969), “American Trade Union Growth: 1900-1960,” Quarterly Journal of Economics.

Sabine Blaaschke (2000), "Union Density and European Integration: Diverging Convergence," European Journal of Industrial Relations, 6(2): 217-236.

Alison Booth, The Economics of the Trade Union, Cambrdige, 1995.

George Borjas (2000), Labor Economics, (New York: McGraw Hill).

Willam Dickens and Jonathan Leonard (1985), "Accounting for the Decline in Union Membership, 1950-1980,” Industrial and Labor Relations Review.

Ronald Ehrenberg and Robert Smith (2000), Modern Labor Economics, (Addison Wesley Longman, Inc).

Henry Farber (1990), "The Decline of Unionization in the United States," Journal of Labor Economics, 8:S75.

Henry Farber and Bruce Western (2001), "Round up the Usual Suspects: The Decline of Unions in the Private Sector, 1973-98" Journal of Labor Research, 2(2): 63-88.

Richard Freeman (Spring 1988), "Contraction and Expansion: The Divergence of Private Sector and Public Sector Unionism in the United States," Journal of Economic Perspectives 2(2): 63-88.

Richard Freeman (April 1997), "Spurts in Union Growth: Defining Moments and Social Processes," NBER Working Paper.

Richard Freeman and James Medoff (1979), "The Two Faces of Unionism,” The Public Interest, Reprinted in Readings in Labor Economics, $3^{\text {rd }}$ edition, L. Reynolds, S. Masters, and C. Moser, eds. (Englewood Cliffs: Prentice Hall) 1982: 398-415.

Walter Galenson (1994), Trade Union Growth and Decline: An International Study, (Westport, CT: Praeger Press).

See Rafael Gomez and Morley Gunderson (2002), "Union Membership as an Experience Good for Youth," paper presented at the Changing Role of Unions, Middlebury College $23^{\text {rd }}$ Annual Conference on Economic Issues, Middlebury, VT.

Masanori Hashimoto (June 1981), "Specific Training as a Shared Investment," American Economic Review, 71(3): 475-82. 
Barry Hirsch and John Addison (1986), The Economic Analysis of Unions, (Boston: Allen \& Unwin).

Barry Hirsch, David Macpherson, and Edward Schumacher, "Measuring Union and Nonunion Wage Growth: Puzzles in Search of Solutions," Paper presented at the Changing Role of Unions, Middlebury College $23^{\text {rd }}$ Annual Conference on Economic Issues, Middlebury, VT.

Bruce E. Kauffman (1994) The Economics of Labor Markets, (The Dryden Press).

M. Kuratani (1973), “A Theory of Training, Earnings and Employment in Japan,” Ph.D.

Dissertation, Columbia University.

Edward D. Mansfield and Brian M. Pollins (forthcoming), New Perspectives on Economic

Exchange and Armed Conflict, (Ann Arbor: University of Michigan Press).

Solomon Polachek (forthcoming), "Trade-Based Interactions: An Interdisciplinary Perspective," Conflict Management and Peace Science.

Solomon Polachek and W. Stanley Siebert (1993), The Economics of Earnings, (Cambridge: Cambridge University Press). 
Table 1

Descriptive Statistics Based on Data Reported in Galenson (1994)

\begin{tabular}{|l|c|c|c|c|c|}
\hline & $\mathbf{N}$ & Minimum & Maximum & Mean & Std. Deviation \\
\hline Industrial Dummy & 25 & .00 & 1.00 & .5200 & .5099 \\
\hline $\begin{array}{l}\text { Growth in Trade as } \\
\text { Percent of GDP }\end{array}$ & 23 & -2.80 & 6.20 & .3565 & 2.3263 \\
\hline Union Density & 25 & 3.20 & 80.00 & 32.5880 & 20.4473 \\
\hline $\begin{array}{l}\text { Union Membership } \\
\text { Growth Rate }\end{array}$ & 25 & -36.80 & 52.20 & -8.6840 & 22.2840 \\
\hline GDP Annual Growth & 25 & -.30 & 9.70 & 3.4520 & 2.2189 \\
\hline $\begin{array}{l}\text { Percent Change in } \\
\text { Manufacturing }\end{array}$ & 22 & -25.00 & 57.40 & -6.0227 & 17.7507 \\
Employment & 25 & 1.30 & 334.80 & 31.7520 & 77.9002 \\
\hline Annual Price Inflation & 25 & 2.10 & 17.50 & 6.5722 & 3.8057 \\
\hline Unemployment Rate & 18 & 24.10 & 11.0826 & 6.6040 \\
\hline $\begin{array}{l}\text { Proportion Female in } \\
\text { Nonagricultural } \\
\text { Employment }\end{array}$ & 25 & -.40 & 5.00 & 3.2000 & .9574 \\
\hline $\begin{array}{l}\text { Government Attitude } \\
\text { Towards Unions }\end{array}$ & 25 & 2.00 & & & \\
\hline
\end{tabular}

See Appendix for variable definitions. 
Table 2

International Differences in Union Density

\begin{tabular}{|l|c|c|}
\hline \multicolumn{1}{|c|}{ Country } & Union Density & 19080-1988 Percent Change \\
\hline Australia & 49 & -14.3 \\
\hline Canada & 35.1 & -1.4 \\
\hline Denmark & 76.5 & -4.3 \\
\hline France & 19 & -36.8 \\
\hline Germany & 37 & -8.6 \\
\hline Italy & 49.3 & -19.7 \\
\hline Japan & 31.1 & -13.8 \\
\hline New Zealand & 55 & -23.5 \\
\hline Norway & 56.9 & 0.4 \\
\hline Spain & 22 & -27.3 \\
\hline Sweden & 80 & 6.6 \\
\hline UK & 50.7 & -18.1 \\
\hline USA & 23 & -28.7 \\
\hline Argentina & 33 & -8.7 \\
\hline Brazil & 13.6 & -7.2 \\
\hline Chile & 37 & -36.4 \\
\hline Egypt & 27 & -5.9 \\
\hline India & 30 & -35 \\
\hline Kenya & 7.2 & -36.1 \\
\hline Korea & 12.8 & 52.2 \\
\hline Malaysia & 10.6 & -4.7 \\
\hline Mexico & 23.4 & 21.9 \\
\hline Philippines & 11.4 & 4 \\
\hline Taiwan & 20.9 & 40.8 \\
\hline Thailand & 3.2 & -12.5 \\
\hline & & \\
\hline
\end{tabular}

Source: Walter Galenson, Trade Union Graoh and Decline (Westport, CT: Praeger), 1994, Tables 1.1 and 1.2 .

Galenson's data sources are: Jelle Visser, "Trends in Union Membership," OECD, Employment Outlook, Paris, 1982, 1985-1991; U.S. Department of Labor, Country Labor Profile and Foreign Labor Trends; and Taiwan Statistical Data Book, 1988. 
Table 3

Covariates of Union Density Growth

\begin{tabular}{|c|c|c|c|c|c|}
\hline Variable & Description & $\begin{array}{c}\text { Simple } \\
\text { Correlation }\end{array}$ & $\begin{array}{l}\text { Coefficient } \\
\text { (t-statistic) }\end{array}$ & $\begin{array}{l}\text { Coefficient } \\
\text { (t-statistic) }\end{array}$ & $\begin{array}{l}\text { Coefficient } \\
\text { (t-statistic) }\end{array}$ \\
\hline $\mathrm{L}_{\mathrm{m}}$ & $\begin{array}{l}\text { Percent change in } \\
\text { Manufacturing Employment }\end{array}$ & .477 & $\begin{array}{l}.475 \\
(0.5)\end{array}$ & $\begin{array}{l}.519 \\
(2.0)\end{array}$ & $\begin{array}{l}.461 \\
(1.6)\end{array}$ \\
\hline $\mathrm{L}_{\mathrm{f}}$ & $\begin{array}{l}\text { Proportion Female in } \\
\text { Non-agricultural Employment }\end{array}$ & -.156 & $\begin{array}{l}-.778 \\
(-.7)\end{array}$ & $\begin{array}{c}-1.138 \\
(-1.6)\end{array}$ & $\begin{array}{c}-1.544 \\
(-2.1)\end{array}$ \\
\hline$Y_{m}$ & $\begin{array}{l}\text { Percent Change in Real } \\
\text { Relative Manufacturing Income }\end{array}$ & .330 & $\begin{array}{l}.400 \\
(0.1)\end{array}$ & $\begin{array}{c}2.098 \\
(0.9)\end{array}$ & $\begin{array}{l}1.753 \\
(0.7)\end{array}$ \\
\hline$Y_{r}$ & $\begin{array}{l}\text { Annual Price } \\
\text { Inflation }\end{array}$ & .038 & $\begin{array}{l}.856 \\
(0.6)\end{array}$ & $\begin{array}{l}.007 \\
(0.8)\end{array}$ & $\begin{array}{l}.004 \\
(0.5)\end{array}$ \\
\hline $\mathrm{Y}$ & GDP Annual Growth & .378 & $\begin{array}{l}5.184 \\
(1.4)\end{array}$ & $\begin{array}{c}3.468 \\
(1.2)\end{array}$ & $\begin{array}{l}1.979 \\
(0.6)\end{array}$ \\
\hline $\mathrm{G}$ & $\begin{array}{l}\text { Government Attitude towards } \\
\text { Union }\end{array}$ & .037 & $\begin{array}{c}4.806 \\
(0.8)\end{array}$ & $\begin{array}{l}7.789 \\
(1.9)\end{array}$ & $\begin{array}{l}.007 \\
(0.1)\end{array}$ \\
\hline $\mathrm{U}$ & Unemployment Rate & -.525 & $\begin{array}{l}-.710 \\
(-.5)\end{array}$ & & \\
\hline CNST & & & $\begin{array}{l}-30.91 \\
(-1.2)\end{array}$ & $\begin{array}{c}-37.112 \\
(-2.2)\end{array}$ & \\
\hline OBS & & & 16 & 22 & 22 \\
\hline $\mathrm{R}^{2}$ & & & .614 & .538 & .521 \\
\hline
\end{tabular}

Dependent Variable: Union Density Growth Rate 


\section{Table 4}

\section{Percent Change in Union Membership (1978 - 1989)}

$\begin{array}{lcc} & \text { U.S. } & \text { Canada } \\ \text { Automobiles } & -35 & 12 \\ \text { Steel } & -71 & -21 \\ \text { Clothing \& Textiles } & -47 & -17 \\ \text { Ladies' Garments } & -50 & -32 \\ \text { Rubbery Linoleum } & -36 & -18 \\ \text { Building } & -21 & -9 \\ \text { State \& Local Government } & 6 & 49 \\ \text { Teaching } & 32 & 20\end{array}$

Source: Galenson, p. 18

(Pradeep Kumar, Industrial Relations in Canada and the U.S. 1991, p. 14) 
Table 5

\section{Percent Labor For Unionized, 1976 by Occupation}

\section{Occupation}

Professional

Managerial

Clerical and Sales

Craft

Operative

Laborer

Farmers

Misc.

Total

\section{Union Membership}

13.1

5

16.7

30.3

50.7

24.4

0

33.3

18.6

\section{Union Coverage}

14.5

8

20

32.5

53.2

28.6

0

33.3

20.4

Source: PSID Data. 
Table 6

\section{Proportion Inter-Occupational Unionization Differences Explained by Trade}

\begin{tabular}{|c|c|c|c|c|c|c|c|}
\hline & Manager & Sales & $\underline{\text { Service }}$ & Clerical & Craft & Laborer & Operative \\
\hline Professional & $10 \%$ & $0 \%$ & $100 \%$ & $100 \%$ & $46 \%$ & $81 \%$ & $43 \%$ \\
\hline Manager & & $0 \%$ & $100 \%$ & $100 \%$ & $52 \%$ & $92 \%$ & $48 \%$ \\
\hline Sales & & & $21 \%$ & $35 \%$ & $22 \%$ & $33 \%$ & $22 \%$ \\
\hline Service & & & & $0 \%$ & $22 \%$ & $63 \%$ & $23 \%$ \\
\hline Clerical & & & & & $10 \%$ & $30 \%$ & $13 \%$ \\
\hline Craft & & & & & & $0 \%$ & $25 \%$ \\
\hline Laborer & & & & & & & $1 \%$ \\
\hline
\end{tabular}




\begin{tabular}{|c|c|c|c|c|c|c|c|c|c|c|c|}
\hline \multicolumn{5}{|c|}{ Appendix A: Galenson International Union Data } & \multirow[b]{2}{*}{$\%$ change } & \multirow[b]{2}{*}{$\%$ growth } & \multirow[b]{2}{*}{$\begin{array}{l}\text { Average annual } \\
\text { price inflation }\end{array}$} & \multirow[b]{2}{*}{$\begin{array}{c}\text { Average annual } \\
\text { unemployment } \\
\text { rate }\end{array}$} & \multirow[b]{2}{*}{$\begin{array}{c}\text { Proportion } \\
\text { nonagricultural } \\
\text { employment female }\end{array}$} & \multirow[b]{2}{*}{$\begin{array}{l}\text { Government } \\
\text { Attitude } \\
\text { towards unions }\end{array}$} & \multirow[b]{2}{*}{$\begin{array}{l}\text { Social Security } \\
\text { Benefits } \\
\text { as } \% \text { of GDP, } 198\end{array}$} \\
\hline Country & $\begin{array}{c}\text { Industrial } \\
\text { Status }\end{array}$ & $\begin{array}{c}\text { Union } \\
\text { Density } \\
1980\end{array}$ & $\begin{array}{c}\text { Union } \\
\text { Growth } \\
\text { Rate } 1980-88\end{array}$ & $\begin{array}{l}\text { GDP Annual } \\
\text { Growth } 80-89\end{array}$ & & & & & & & \\
\hline Australia & 1 & 49 & -14.3 & 3.5 & -21.2 & 0.2 & 7.8 & 7.5 & 12.9 & 5 & 9.1 \\
\hline Canada & 1 & 35.1 & -1.4 & 3.3 & -14.4 & 0.4 & 4.6 & 7.3 & 10.6 & 3 & 15.6 \\
\hline Denmark & 1 & 76.5 & -4.3 & 2.2 & -11.3 & 0.5 & 6 & 8.9 & 0.1 & 3 & 25.5 \\
\hline France & 1 & 19 & -36.8 & 2.1 & -19.3 & 1.2 & 6.5 & 9 & 8.2 & 4 & 27.2 \\
\hline Germany & 1 & 37 & -8.6 & 1.9 & -7 & 1.7 & 2.7 & 5.9 & 4.8 & 3 & 22.7 \\
\hline Italy & 1 & 49.3 & -19.7 & 2.4 & -15.9 & 0.8 & 10.3 & 9.5 & 8.7 & 3 & 10 \\
\hline Japan & 1 & 31.1 & -13.8 & 4 & -4.5 & 1.7 & 1.3 & 2.5 & 9.3 & 3 & 11.5 \\
\hline New Zealand & 1 & 55 & -23.5 & 2.2 & -25 & -1 & 11.4 & 5.1 & 10.8 & 4 & 17.4 \\
\hline Norway & 1 & 56.9 & 0.4 & 3.6 & -25 & 1.7 & 5.6 & 2.7 & 9.5 & 5 & 29.5 \\
\hline Spain & 1 & 22 & -27.3 & 3.1 & -17.6 & 0.8 & 9.4 & 17.5 & 19.9 & 4 & 17.2 \\
\hline Sweden & 1 & 80 & 6.6 & 1.7 & -9.9 & 0.6 & 7.4 & 2.5 & 3.4 & 5 & 30.1 \\
\hline UK & 1 & 50.7 & -18.1 & 2.6 & -7.3 & 2.8 & 6.1 & 10 & 10.9 & 2 & 19.4 \\
\hline USA & 1 & 23 & -28.7 & 3.3 & -20 & 1.8 & 4 & 7.2 & 24.1 & 2 & 12 \\
\hline Argentina & 0 & 33 & -8.7 & -0.3 & -999 & 1.4 & 334.8 & -999 & -999 & 3 & -999 \\
\hline Brazil & 0 & 13.6 & -7.2 & 3 & -5.4 & 0 & 227.8 & -999 & 14.5 & 3 & -999 \\
\hline Chile & 0 & 37 & -36.4 & 2.7 & 5 & -1.7 & 20.5 & -999 & 7.1 & 2 & -999 \\
\hline Egypt & 0 & 27 & -5.9 & 5.4 & -999 & 0.5 & 11 & -999 & -999 & 3 & -999 \\
\hline India & 0 & 30 & -35 & 5.3 & -4.9 & 3.4 & 7.7 & -999 & 17.7 & 4 & -999 \\
\hline Kenya & 0 & 7.2 & -36.1 & 4.1 & -7.1 & -0.1 & 9 & -999 & 14.3 & 2 & -999 \\
\hline Korea & 0 & 12.8 & 52.2 & 9.7 & 12.2 & 5.9 & 5 & 3.8 & 12.5 & 3 & -999 \\
\hline Malaysia & 0 & 10.6 & -4.7 & 4.9 & -3.7 & 4.4 & 1.5 & 7.4 & 24.1 & 3 & -999 \\
\hline Mexico & 0 & 23.4 & 21.9 & 0.7 & 57.4 & -5.2 & 72.7 & -999 & 4.6 & 4 & -999 \\
\hline Philippines & 0 & 11.4 & 4 & 0.7 & -2.8 & 4 & 14.8 & 6.6 & -0.4 & 3 & -999 \\
\hline Taiwan & 0 & 20.9 & 40.8 & 7.2 & -999 & 6.9 & 2.7 & 2.1 & 17.5 & 2 & -999 \\
\hline Thailand & 0 & 3.2 & -12.5 & 7 & 15.2 & 6.3 & 3.2 & 2.8 & 9.8 & 2 & -999 \\
\hline & & & & & & & & & & & \\
\hline \multicolumn{12}{|l|}{ Key } \\
\hline \multicolumn{12}{|c|}{ Industrial Status: 1 represents industrial country and 0 represents develping country } \\
\hline \multicolumn{12}{|c|}{ Union Density is union membership as a proportion of employed wage and salaried workers. } \\
\hline \multicolumn{12}{|c|}{ Union growth is the $1980-1988$ percent change in union density. } \\
\hline \multicolumn{12}{|c|}{ GDP Annual growth 80-89 is the average annual growth. Galenson's Source is: World Bank, World Development Report, World Tables, 1991.} \\
\hline Government $A$ & Attitude towa & ards unions & s: 1 - unions ban & nned or under gov & vernment co & ontrol; 2- em & nployers favored by & y govt; & & & \\
\hline
\end{tabular}




\section{IZA Discussion Papers}

\begin{tabular}{|c|c|c|c|c|}
\hline No. & Author(s) & Title & Area & Date \\
\hline 882 & $\begin{array}{l}\text { A. Lindbeck } \\
\text { D. J. Snower }\end{array}$ & The Firm as a Pool of Factor Complementarities & 5 & $10 / 03$ \\
\hline 883 & $\begin{array}{l}\text { S. Groeneveld } \\
\text { J. Hartog }\end{array}$ & $\begin{array}{l}\text { Overeducation, Wages and Promotions within } \\
\text { the Firm }\end{array}$ & 5 & $10 / 03$ \\
\hline 884 & $\begin{array}{l}\text { J. Masso } \\
\text { A. Heshmati }\end{array}$ & $\begin{array}{l}\text { The Optimality and Overuse of Labour in } \\
\text { Estonian Manufacturing Enterprises }\end{array}$ & 4 & $10 / 03$ \\
\hline 885 & $\begin{array}{l}\text { A. Constant } \\
\text { K. F. Zimmermann }\end{array}$ & $\begin{array}{l}\text { The Dynamics of Repeat Migration: A Markov } \\
\text { Chain Analysis }\end{array}$ & 1 & $10 / 03$ \\
\hline 886 & $\begin{array}{l}\text { J. J. Dolado } \\
\text { M. Jansen } \\
\text { J. F. Jimeno }\end{array}$ & $\begin{array}{l}\text { On-the-Job Search in a Matching Model with } \\
\text { Heterogenous Jobs and Workers }\end{array}$ & 1 & $10 / 03$ \\
\hline 887 & $\begin{array}{l}\text { B. Irlenbusch } \\
\text { D. Sliwka }\end{array}$ & $\begin{array}{l}\text { Transparency and Reciprocal Behavior in } \\
\text { Employment Relations }\end{array}$ & 7 & $10 / 03$ \\
\hline 888 & W. Koeniger & $\begin{array}{l}\text { Collective Dismissal Cost, Product Market } \\
\text { Competition and Innovation }\end{array}$ & 3 & $10 / 03$ \\
\hline 889 & D. E. Wildasin & $\begin{array}{l}\text { Fiscal Policy, Human Capital, and Canada-US } \\
\text { Labor Market Integration }\end{array}$ & 2 & $10 / 03$ \\
\hline 890 & $\begin{array}{l}\text { M. Bratti } \\
\text { L. Mancini }\end{array}$ & $\begin{array}{l}\text { Differences in Early Occupational Earnings of } \\
\text { UK Male Graduates by Degree Subject: } \\
\text { Evidence from the 1980-1993 USR }\end{array}$ & 6 & $10 / 03$ \\
\hline 891 & $\begin{array}{l}\text { L. Flood } \\
\text { E. Pylkkänen } \\
\text { R. Wahlberg }\end{array}$ & $\begin{array}{l}\text { From Welfare to Work: Evaluating a Proposed } \\
\text { Tax and Benefit Reform Targeted at Single } \\
\text { Mothers in Sweden }\end{array}$ & 6 & $10 / 03$ \\
\hline 892 & B. T. Hirsch & What Do Unions Do for Economic Performance? & 5 & $10 / 03$ \\
\hline 893 & K. Sabirianova Peter & $\begin{array}{l}\text { Skill-Biased Transition: The Role of Markets, } \\
\text { Institutions, and Technological Change }\end{array}$ & 4 & $10 / 03$ \\
\hline 894 & R. Winkelmann & Parental Separation and Well-Being of Youths & 7 & $10 / 03$ \\
\hline 895 & $\begin{array}{l}\text { J. M. Fitzgerald } \\
\text { D. C. Ribar }\end{array}$ & $\begin{array}{l}\text { Transitions in Welfare Participation and Female } \\
\text { Headship }\end{array}$ & 3 & $10 / 03$ \\
\hline 896 & S. W. Polachek & $\begin{array}{l}\text { What Can We Learn About the Decline in U.S. } \\
\text { Union Membership from International Data? }\end{array}$ & 2 & $10 / 03$ \\
\hline
\end{tabular}

An updated list of IZA Discussion Papers is available on the center's homepage www.iza.org. 